concerned in an obscure project of the pirate Strangways for the capture of the Portuguese stronghold of Mina in Guinea, which was but thinly disguised as a trading venture, and which ended in the seizure and trial of the adventurers. Their examination was held before the judges of the Admiralty Court, and in Strangways' evidence it is stated that 'he had information of the plot of Martin Frobisher, and hath talked also of this matter with one John Locke. ${ }^{12}$. Martin Frobisher was privy also to his intent in talk, and should have gone with him to the Enterprise to the Castle of Mina, but came not.' ${ }^{13}$ There is no indication as to the nature of the plot in question, but the association of Frobisher's name with the enterprise shows clearly that his early interest in the Guinea trade had been maintained; and it is evident from the nature of the proposed expedition that he was not only concerned in legitimate trade, but had already become involved in piratical ventures such as those in which he is known to have been engaged between 1563 and 1573 .

K. M. Euior.

\title{
Letters illustrating the Relations of England and Russia in the Seventeenth Century
}

THE archives of the Board of Foreign Affairs at Moscow contain, in the class of 'English Letters', a long correspondence betwéen the Russian and English courts, beginning with the reign of Queen Elizabeth. Under the Stuarts the letters are written in English, in large clear characters with few abbreviations. They all bear the royal signature. A feature of the letters of the latter part of James I's reign and of the earlier part of Charles I's is the elaborate style of their ornamentation, the initial letter of the king's name being decorated with a handsome miniature of considerable dimensions. This miniature may include a portrait of the king enthroned or figures of animals, flowers, \&c. Coats of arms and symbolical ornaments are sometimes depicted on a broad coloured stripe which traverses the upper and the side margins. The first line of the king's title is written in large gold characters on a blue or (especially when the letter is addressed not to the tsar but to the patriarch) on a dark red ground. In the latter part of Charles I's reign this coloured ground no longer appears, and the margins are left plain: Under Charles II more gold is used for the ornamentation and for capital letters, but the floral

${ }_{12}$ Brother of Frobisher's associate Michael Locke, and a member of the original Guinea Company.

13 Admiralty Court Examinations, 1559-65, 35. 
decorations are rarer: One letter written from Saint-Germain is illuminated in a delicate French style. The following transcripts are taken from the originals, with omission of the king's title and the address giving the 'grand title' of the tsar.

1. The first letter relates to the mission of Sir John Merrick, who was first principal agent and then governor of the Muscovy Company, and who was appointed on 18 June 1614 ambassador to the tsar to treat for peace between him and Gustavus Adolphus of Sweden. ${ }^{1}$ He visited the Swedish king at Narva and afterwards went to the village of Dederino, where the first negotiations took place; the Dutch mediators supported the side of Sweden, while Merrick was believed to favour Russia. In any case he had a very important part to play, and the Swedish deputies more than once declared that he held peace in his hands ; ${ }^{2}$ he wrote several times to the Swedish king and to the tsar, and also sent reports on the negotiations to England. ${ }^{3}$ At his instance Michael wrote to James I (18 August 1615), informing him of the ill-success of the first negotiations and asking for his assistance in case of war being resumed. . The letter we print is an answer to this. 4 Later the negotiations were continued at Tikvino and Stolbovo; the Dutch mediators had departed, but Merrick remained until the end, and peace was definitively signed in his presence in February 1617: After that he was received with great pomp in Moscow and obtained rich presents from the tsar with his portrait on a gold chain to wear on his breast. ${ }^{5}$

2. The second letter illustrates the commercial relations between England and Russia. The privilege here mentioned was granted by Tsar Michael in July 1617.6 It empowered twenty-three members of the Muscovy Company and their factors to trade throughout the tsar's dominions free of customs. But in spite of this we see from the letter that toll and custom were sometimes exacted and, we may add, never returned; this was

1 His commission is printed in Rymer's Foedera, xvi (1715), $768 \mathrm{f}$. See also State Papers, Russia, ij, fo. 215, 261, in the Public Record Office; and a letter from Merricli to Secretary Winwood, December 1615, ibid., fo. 216.

3. The details of these negotiations may be found in the Sbornik Imp. Ystoritch. Obtchestva, xxiv. (Petrograd).

3 State Papers, Russia, ii, fo. 224, a letter to Winwood with Merrick's seal, dated 10 August 1616. His letters to Gustavus Adolphus are printed by Lygin, Stolbovsky dogovor. See also Add. MS. 35125, British Museum. An answer of the tsar to Merrick is in Lygin, no. 38.

- Another letter from James, dated 16 April 1616, is preserved in Moscow (no. 23), but unfortunately it is quite defaced.

- Massa, Histoire des Guerres de la Moscovie, ii, Introduction, p. cvii. For more particulars as to Merrick's see my paper on the correspondence and diplomatic relations of the first Romanovs with the first Stuarts in the Jurnal Ministerstva Narodnago Prosvetchenia, July 1915.

- See English Treaties, no. 6, in the archives of the Board of Foreign Affairs at Moscow. 
the half-custom, which was exacted from all foreigners in Russia, except the English.

The letter speaks of the Company as 'trading in several and apart', that is as a regulated company. 'Though the Muscovy Company was the first joint-stock company of the sixteenth century, ${ }^{7}$ in the seventeenth an attempt had been made by its members to give a new and looser organization to the trade, in the hope of checking its decline and of attracting new capital. A letter of King James, dated 30 May 1623, announced to the tsar this decision. 8 In earlier times, when the mercantile energy of the English pioneers had been of great assistance to the external commerce of Russia, Tsar Ivan IV and Tsar Boris had asked Queen Elizabeth that the English trade in Russia might be kept free; but later, when many other nations were already trading with good success in the Muscovite markets and paying large customs to the government, Tsar Michael showed a marked reluctance to increase the number of privileged English merchants in his empire, and permission for the reorganization of the Company was several times refused. The Company had houses in Moscow, in Yaroslavl on the Volga, and in the north of Russia, in Vologda, Kolmogory, and Arkangelsk, ${ }^{9}$ one house in each. The petition of 1627, that the English might be allowed to live in each town in several houses or obtain ground for new buildings, was also rejected, and they were only permitted to buy a new house in Moscow; but the Company was already too poor for such an expense. The first house in Moscow had been granted by Tsar Ivan at the time of the first privilege to the Company in $\mathbf{1 5 5 5}$.

When the letter more than once mentions the 'league' and 'alliance" between England and Russia, these words are to be understood only as terms of amity and friendship between the countries. A league, as a political and commercial alliance, had been discussed in the reign of King James, and in 1623 was nearly concluded, ${ }^{10}$ but the project failed at that time and was not taken up in the reign of Charles.

3. The Patriarch Philaret, to whom the third letter is addressed, was the father of the young Tsar Michael. During the 'period of troubles' he had been sent on an' embassy to Poland to

- See W. R. Scott, Joint Stock Companies to 1720; Gerson, The Organization and Early History of the Muscovy Company, pp. 37-42 ; and the present writer's article 'on 'Les Marchands Anglais en Russie au XVI' ${ }^{\text {me }}$ Siecle' in the Revre Historique, cix. 6-7, and Ystorija torgovyk snoshenij Rossii \& Angliej, i. 27-30.

- English Letters, no. 34 (original), and State Papers, Russia, ii (copy).

- See the privilege of $\mathbf{1 6 1 7}$.

${ }^{10}$ Rymer, Foedera, vii, p. iv, pp. 71-3, 'Articles of a perpetuall League of Amity and Alliance, Entercourse and Commerce accorded and agreed uppon betweene the most high and mighty Prince James . . . and the great Lord Emperour and great Duke Michall Theodorowith.' See also my article (cited above, n. 5), pp. 86-93. 
promote the candidature of Vladislas to the Muscovite throne. As no agreement was arrived at, the Russian ambassadors were for a long time detained in Poland as prisoners, and Philaret did not return to Moscow until 1619, when his son had already. been reigning for six years. He was immediately nominated patriarch of Moscow, and thenceforward took a prominent part in the government. Many of the English kings' letters were addressed in two, though not quite identical, forms : one to the tsar, the other to the patriarch.

In 1631 Russia was reorganizing its army and accepting soldiers, officers, and ammunition from abroad. The 2,000 muskets mentioned in the letter form a small part of the military help given by England to Tsar Michael.11 In return for English services of that kind, King Charles several times asked Russia for corn, wheat, buckwheat, \&.c. In the years 1628-32 there were bad harvests in Eastern Europe, the prices of grain rising dangerously in England after 1628. Sixteen letters of the correspondence with the Russian court treat the question of export of grain from Russia. ${ }^{12}$ But though great quantities were demanded and various persons sent from England with privileges to buy them on the Russian markets, the tsar contributed no more than the 30,000 chetverts mentioned in this letter. The reason for their refusal was not so much the supposed scarcity of grain in Russia, as the lack of co-ordination in the action of the English Company and of Charles I; the king needed money and gave letters of recommendation to persons of bad reputation, if they paid him for them.

4. Tar was a much-needed article of English importation from Russia, and a great quantity of it was also used at the English rope-works in Vologda and Kolmogory. Established since the sixteenth century, the English employed workmen brought from England, but the Russians soon began to learn from them, and with good success. The ropes, always improving in quality, were imported in large quantities into England, where the chief buyer was the treasury itself. As early as $1588,3,000 \mathrm{lb}$. of rope had been ordered from Moscow, and in 1594 the orders amounted to $13,500 \mathrm{lb}$. It is no exaggeration to say that at the end of the sixteenth century the English fleet obtained its rigging from Russia. ${ }^{23}$ In the letter printed below Charles I asked on 25 March 1636 for a licence for a limited import of tar. The answer to it, dated 11 January 1638, was a refusal, Michael alleging that the

"The tsar, in a letter dated 29 November 1630 , had asked for these ' 2,000 good muskets and other military ammunition ': Public Record Office, Royal Letters, 49.

is See, for example, English Letters, no.40,12 April 1628; no. 41, 31 October 1629; nos. 48 and 49, 10 August 1630 ; no. 51, 10 September 1630.

${ }^{13}$ See, for example, English Affairs (Moscow), 1622, no. 2; 16 March 1625, no. 4 ; 27 May 1627 , no. 1 ; 9 May 1628, no. 1 ; 4 June 1631, no. 2. 
privilege.was already acquired by, the Dutch for five years, and only permitting the English merchants to buy tar for their rope-works in Kolmogory and Arkangelsk. ${ }^{14}$

5. The last letter here printed illustrates the attitude adopted by Tsar Alexis after the execution of Charles I. In a protest to the European courts he spoke of the king as a 'glorieux martyr', and he expelled the English merchants from Russia on the ground that ' they with all their country had committed a great crime'. Cromwell's attempts to renew relations with Russia were unsuccessful ; his ambassadors were not received at the court. ${ }^{15}$ The letter is a grateful acknowledgement by Charles II of a loan which the tsar had made him. While the abolition of the privileges of the Muscovy Company was immediately due to the revolution in England, it had in reality deeper causes which continued in operation after the restoration of the Stuart house. In the sixteenth century the English had enjoyed exclusive favour in Russia, but after that their position declined. Not only had they to face competition from other traders, but their privileges became incompatible with the economic development of the country: If they had been willing to abandon in time their exemption from customs and to contribute with other foreigners to the resources of the Russian treasury, they might have succeeded in maintaining a firmer hold upon the Muscovite markets.

INNA LUBIMENKO.

English Letter 24.

I

King James I to Tsar Michael

30 September 1616.

Sir John Merrick Knight, our ambassador resident with your Maiestie, haueing by a gentleman of his traine (expresly sent hether to that purpose) advertised vs at large of what hath passed in his negotiation there, namely touching the treatie of peace between your Majestie and our good brother the King of Sueden, wherein wee haue well obserued your princely readines to conforme your selfe to all good causes, tending to a good issue of the said treatie for the general good of Christendome and the particuler benefit of the crownes and subiects of both your Majesties; wee haue thought good by theis our royal letters to take notice of that your peaceable and princely disposition, which wee do highly commend. And for that (as wee are given to understand by our said ambassador) your conformity therein did the more readily extend itselfe in respect of our mediation, wee will in requital thereof the more plentifully supplie (with our royal intervention) all conuenient helpes, that shalbe requisite to the advanceing of that peace to your Majesties best contentment. In consequence whereof wee now againe write to our brother the King of Sueden, exhorting him not to be colde in so good a work, but

16 English Letters, no. 79.

1s See the letters of William Prideaux, Crom well's agent, printed in the Thurloe Papers. 
seeing your Majesties real and sincere forwardnes therin, to answere the same with a reciprocal roundnes, whereinto wee hope he wil incline at the intercession of vs, who haue been the happie instrument of makeing the late reconcilement between him and our dearest brother the King of Denmark. But if (which God forbid) the intended peace shal not succeed and that your Majestie, after a constant imploying of your best endeavor, shalbe forced to reenter into the warre, wee are well pleased in such case, that our subiects of either or all our kingdomes shal in competent numbers with our free leaue serue your Majestie in those warrs, vpon such reasonable termes as shalbe agreed on between your Majestie and them. And in the meanetime, whilst the afforesaid treatie shalbe in handling, wee haue prohibited any more such leuies to be made, as the King of Suedens ministers did here make this sommer past. For all other matters concerning our affaires wee referr you to the report of our ambassador, to whom wee pray you to continue your fauorable regard and to giue him such credite as to our selues in person. And so wee commit your Majestie to the Almighties protection. Giuen vnder our Priuie Seale at our pallace of Westminster, the thirtieth day of September in the thirteenth yeare of our raigne of great Brittaine.

JAMES R.

English Letter 37.

II

King Charles I to Tsar Michael

1 February 1626/7.

Most excellent Prince, most deare brother. and frend, wee doe well vnderstand by your Majesties letters vnto vs in March last, how acceptable our lettres of princely congratulation were to your Majestie, our dearest brother; what singuler content your Majestie tooke in our peaceable entrance and happie succession vnto the crownes and kingdoms of our late deare father, King James of ever blessed memorie, and what royall affection you beare to the conseruation of that princely league and mutuall frendshippe, so happily continued betweene our said deare father and your Majestie, our good brother. In the next place your Majestie, together with your noble father, our deare cozen and frend, the great Lord Feloret Nikitich, the holie Patriarch of Mosco and of all Russia, are pleazed to expresse your good affection towards vs, in the persons of our loving subiects, our marchants trading into your Majesties kingdoms, by graunting them gratious priviledges of free commerce and trade in all your dominions. Theis your Majesties princely expressions by your loue and good will to vs and those reall acts of grace and favour to our marchants, as we do verie well knowe, proceed of your intire affection to vs and our kingdoms, so we, being no lesse carefull to preserue, then our deare father was studious to begin this strickt alliance and brotherly amitie betweene yours and our crownes, do promise in the word of a King to answere those sweet effects of brotherly loue and respect in your Majestie by all the like roiall expressions on our part (in what soeuer maie tend to the happie conseruacion of that auncient league of loue and amitie and increase of all good intelligence betwene your Majestie and vs and betweene our crownes and people); we thought it therfore verie fit to take this opportunitie 
to congratulate with your Majestie the firme and setled estate and constant continuance of your happie raigne and peaceable government over those your great kingdoms of Russia \&c., as also your happie coniunction and marriage with that great and noble Lady, your Majesties most deare affected Empresse and consort, wherin we wish vnto your Majestie, our good brother, all perfection of happines.

For that point of your Majesties lettres, concerning the furnishing of your treasury with the commodities of our kingdoms and the abuse by falsifieng of wares by divers strangling traders, that haue recourse into your Majesties Dominions, we haue giuen charge to our seruant, Sir John Merick Knight, governor of the company of our marchants, to take care heerin, who, we do not doubt, in his due obedience to our command, wil aswell heere, as our agent Fabian Smith in Russia ${ }^{1}$ (to whom wee haue giuen the like command), take good course heerafter both for the reasonable furnishing of your Majesties treasurie, as hath beene heertofore, and for suppressing those strangling traders, the authors of such abuses. Your Majestie our good brother wilbe pleased to take notice, that according to your princely lettres vnto vs by the Grecian friers, Kirila the Archimandrett of Arkania and Gregorie the Archimandrett of Savona Monastery and their fellowes, we haue receaued them with all humanitie and favor, admitting them to our princely hand and giuing them that freedome and entertainment, during the time of their stay in our kingioms, and frendly dispatch home to their owne contrey, as might testifie our good respect to your roiall recomendacion. Now, most deare brother, as nothing sutes better to our princely and brotherly amitie, then thus to imbrace all good occasions with your Majestie, and finding by long and certaine observacion and experience, that the inlarging of the intercourse of trade and commerce betwene our contreys and dominions will much conduce to the honor and commoditie of both our kingdoms and dominions and to the cherishing of the mutuall loue and amity betwene the same, we thought good to take into our especiall consideracion an overture, formerly made by a principall noble-man of your Majesties court to our agent Fabian Smith, concerning the trade of silk to be yearly brought out of Persia through your Majesties dominions; and for that cause we haue called our marchants that trade into your kingdoms before vs and declared vnto them, how earnestly we desire, that this trade of silk 2 should be setled in your Majesties dominions rather then in any other kingdome; and finding them not only conformable to our mind and pleasure heerin, but verie propensiue and ready also to any thing that may tend to the advancement of your Majesties service, we held it very reasonable for their more incouragment to grant and impart vnto them

1 A later commission to Fabian Smith as the king's agent to the tsar and the patriarch of Moscow, dated 12 June 1630, is printed in Rymer's Foedera, xix (1732), 168 f.

2 The trade in silk, brought from Persia through Russia, of which King Charles speaks as of something very advantageous and desirable for both kingdoms, was in reality one of the chief requirements of the Company. The English merchants had made large profits from this trade in the sixteenth century, but failed to re-establish it in the seventeenth, the Russian government being then firmly resolved to exclude foreigners from Persia. 
this our roiall assistance by our lettres to your Majestie our deere brother, heerby lovingly intreating your Majestie to vouchsafe them your princely favour in the particulars heervnto apparteining.

And because diuers of our marchants, since the graunting of the last gratious priviledge by your Majestie our good brother, are departed this life and others againe lefte their course of trade and dealing in marchandize, we lovingly intreate your Majestie; that as you were pleazed at our instance and request to grant them these priviledges, so you will now also be pleased for our sake to strengthen the same with such immunities and favours (the trade being managed in severall and apart), as was formerly granted by your Majestie, at the instance and request of our deare father of ever blessed memory, when the trade was carried in a jointstock, and that such others of our marchants, as are free of that companie, may be incerted in the priviledge in place of those, which are dead and haue lefte the trade, wherby the same may with better effect be managed and carried by them and their successors. And wheras we have viderstood, that some of your Majesties officers, not well vnderstanding the princely priviledges, granted by your Majestie and your noble predecessors vnto our marchants, in contemplacion of the amitie betwene our crownes and kingdoms on both parts, haue lately taken of some of our marchants the tolle and custome due by: other strangers, not comprehended in our mutuall princely league, we pray your Majestie our good brother to give order for the rectifieng of this error by repaiment of the sommes so taken, contrary to your Majesties intents in that behalfe. And in regard the straightnes of roome in our said marchants houses, by reason of their trade in seuerall, is such, that they cannot with conveniency mannage their trade in one house in a place, we pray your Majestie our good brother to grant them libertie to stand in seuerall houses, everie one apart by himself, or to grant them such grounds in the severall places of their trade, as may conueniently serue to build houses for such of them, as cannot stand in the houses already given them by your Majestie.

Wee thanck your Majestie our good brother for your grace and bountie to our subiect Doctor Arthur Dee, ${ }^{3}$ servant and phisition to your Majestie,

3 Arthur Dee was the son of the famous mathematician, John Dee. He studied medicine at Oxford, and was sent with the recommendation of James I (11 June 1621, English Tetters, no. 29) to the tsar in 1621, and continued in his service until 1634. In 1626 he had been allowed to visit England, which was a great favour, rarely granted by the Russian government to any foreigners who had constant access to the court, for fear of their divulging secret information about Russian affairs. In 1627 he re-entered the tsar's service (see a special letter of recommendation, given to him on his return to Russia and dated 2 June 1627, English Letters, no. 39). There were then six foreign doctors at the court, but the tear showed a marked preference for Dee, giving him a yearly salary of more than 1,100 rubles, a very large sum for that time, and granting him a house in Moscow and a valuable estate (Richter, Geschichte der Medicin in Russland). During his life in Russia Dee wrote a scientific work entitled Faseiculus chimicus, abstrusae hermeticae scientiae ingressum, progressum, coronidem, explicans, and published at Paris in 1631. It was translated into English by Elias Ashmole in 1650. After his return to England he served King Charles. I for some time; he died in 1651. Compare the article on Dee in the Dictionary of National Biography. 
by whose humble acknowledgments we haue good testimony of your great and gracious favor towards him, we pray your Majestie for the continuance of this your grace and favor during his stay in your Majesties service, which we are the rather moved to desire, both in regard of his faithfull observance to our deare mother of ever blessed memory all the time of his service about her roiall person, and for the generall approbacion of his worth by our Colledge of Doctours, for which also our deare father of ever blessed memorie held him worthy of his speciall commendacion to your Majestie. Wee haue purposely sent to your Majesties court this gentleman Richard Swift, our special messenger, one formerly imploied to your Majestie our good brother by our said deare father of ever blessed memorie, and haue ordered him to ioyne with our Agent Fabian Smith in the conduct of our affaires and to returne vnto vs with such busines, as shalbe occasioned from your Majestie; wee pray your Majestie our good brother to giue full credit vnto them in what they haue to propound and negotiate in our name, as we shall vpon all occasions readdily do to any thus commended from $\gamma$ our Majestie. It remaines that we giue to your Majestio our good brother all princely assurance, aswell on our part of the like grace and favor in our kingdoms to any of your subiects, that shalbe recommended from your Majestie, as on the part and behalfe of our marchants, that your Majestie shall find them persons everie way so humane and ready to answere your Majesties expectation and so faithfull in their performances, as greater shall not be found from any people or nation negociating with your Majestie or people. And thus we wish vnto your Majestie long and happie felicity on earth and everlastinge in heaven. Given at our pallace of Whithall the first day of Februarie, in the yeare of our Lord 1626 and of our raigne of great Brittaine, France and Ireland. the second.

Charles R.

English Letter 59.

III

\section{King Charles I to the Patriarch Philaret}

20 May 1631.

Most reuerend great Lord our deare cousin and frend.' Wee haue understood by seuerall letters receaued from our good brother, the great. Lord Emperor and great Duke Michaell Feodorowich of all Russia sole commander, your renowned sonne, and from your Grace our good cousin, that our letters were honorablie receaued of you both. Wee are also informed that our marchants, by the speciall grace and fauor of his Majestie and your selfe, haue both obteined theire ancient priviledges and, as wee suppose (hearing nothing to the contrarie), haue gotten libertie to go with their shipps ouer the new barre at Mormensky ${ }^{4}$ and (which

- The bar of 'Mormensky' is mentioned several times in the correspondence. The river of the North Dvina, where the ships coming by the Baltic to Russia landed, having several mouths, the English had received in the sixteenth century permission to land at the 'Pudozemskoe' mouth; but after 1629 we find their petitions to the Russian government, asking to be allowed to pass to Arkangelsk by the newly discovered bar ('Berezovoe' or 'Murmanskoe'), on account of the shallowness of the water in the old bar. In a letter dated 8 June 1632 (State Papers, Russia, ii, fo. 138-40), Charles cites serious accidents which ships had suffered in passing by the old 'Pudo. zemskoe' bar. But these representations, however well justified, led to no result. 
importeth them much) haue for theire protector in theire affaires assigned to them (according to our desire) a nobleman of honor and trust and of neare accesse to you both. 5 Now for theise expressions of a louing affection towards vs we are verie thankefull and will returne the like good offices upon all occasions on our part. For the present, according to that desired by his Majestie our good brother, we haue giuen order aswell to the gouernor of the companie of our marchants here trading in Russia, as also to John Cartwright (who came ouer for this busines) for the prouision and free transportation of two thousand muskets for his Majesties seruice. And for anie that shall attempt the preiudice and hurt of his Majestie our deare brother or his estates, wee will not onelie giue no encouragement or assistance to them, but contrariwise will by all meanes disswade and hinder such uniust practises, and in what wee may, procure and further the peace and tranquillitie of that great empire, wherewith wee and our noble progenitors haue had ancient and firme alliance, which wee will alwayes endeuor to preserue for the good of both our crownes and kingdomes. Wee have also giuen order in our universitie of Cambridge and with our colledge of Doctors in London for the perfect instruction of John Elmson, ${ }^{6}$ the sonne of John Elmson, in the studie of phisicke for his Majesties seruice, and for defraying of bis necessarie charge here when he shall returne out of France. And whereas by your last letter it pleased your Grace our deare cousin to signifie unto vs that you had cawsed our factor Thomas Wiche to bee furnished this last yeare with thirtie thousand chetfords ${ }^{7}$ of seuerall sorts of graine, and that more could not then be granted by reason of the barrenesse of that season, wee doe give his Majestie our good brother and your Grace our deare cousin verie hartie thanks for this your noble courtesie. And for the remainder of the hundred thousand chetfords which wee formerlie desired, wee hope and now desire againe (for the same urgent and pressing occasions mentioned in our first letters) through your Graces fauor, our good cousin, God sending better store, it may be supplied to our said factor Thomas Wiche the next winter. Our pleasure herein and the furtherance of this our seruice wee haue imposed by speciall chardg to our agent Fabian Smith. Lastlie for that wee haue bene informed, that some haue attempted to offer wrongs and to cast aspersions upon our subiects in Russia, which reports as wee are not apte to beleeue, so wee are confident that, neither his Majestie our

s This desire of the merchants, to have a special protector, after the example of Boris Godunov, who had received this office in the sixteenth century, obtained no success, and the supposition made in this letter, that this matter had been happily settled, is quite unfounded.

- Elmson was not Russian by blood, but the son of an interpreter, serving at the tsar's court. Tsar Boris had already made a plan for sending young Russians abroad for their education; and four of them had been taken to England by John Merrick. The result was curious. In the time of the troubles they were forgotten, and when they were recalled by Tsar Michael, they showed no desire to return, and Charles refused to send them back by force (State Papers, Russia, ii, fo. 103, 116). Probably for that reason Michael chose only sons of interpreters to be educated abroad. Elmson and Almanzenov are mentioned several times, as having gone to England for medical study. It is interesting to note that Charles was 'defraying the necessarie charge' of Elmson during his stay in England.

7 A Russian dry measure. 
good brother, nor your Grace our good cousin, in regard of your great wisdomes and good affection towards $\mathrm{vs}$, will not give credit to such detractors, nor leaue unreprooued and unpunisht the raisers of such false rumors, which good princes can in no wise abide or suffer. And so wee pray your Grace our good cousin to rest assured of our perticuler fauor and respect to your person and dignitie. Given in our Imperiall cittie of London in our pallace of Westminster, the yeare since the birth of our Lord and Sauiour Jesus Christ 1631, the 20th day of May.

Charles R.

English Letter 71 .

IV

King Charles I to Tsar Michaed

25 March 1636.

Most excellent Prince our most deare brother and frend. Your royall disposition and good affection towards vs, abundantly testified by your last letters, sent by your owne messenger or post, and also by the entercourse of many frendly offices betwixt vs, giue vs confidence that your Imperiall Majestie our deare brother will gratifie vs in that, which without preiudice to your affaires may accommodate our nauye, which is an important part of that power wee haue to assist our good frends and annoye our ennemies, when there shalbe cause. To fitt our shipps for seruice from time to time, requireth a conuenient prouision of tarre, which is a commoditie abounding in your great and spatious dominions, but prohibited to be exported without your Majesties speciall license. Wee do therefore by thiese our royall letters recommend to your fauor the bearer, our seruant and factor Henry Thurstone, to whome wee desire you, our deare brother, to grant license and free power to buy of your people, within your said dominions and countreys, three or fower thousand hogsheads of tarre yearly for seuen yeares together, as hee or his agents can best procure it of them. And this being for the seruice of our owne ships of warre, wee doubt not but you will permit it (as you do our marchants goods) to be exported custome free. And with that your Majestie will give order to the officers of all your Majesties castles and mart townes, that they permit and suffer our said factor and his agents, as to buy, so without hinderance or molestation quietlie to shippe and export the said tarre for our seruice. This wee shall receaue from you, our deare brother, as a pledge and assurance of your continewed loue and fauor, which wee will requite on all occasions, wherein our like harty affection towards your Imperiall person and for the aduancement of your affaires may reasonably bee expected. Giuen in our Imperiall cittie of London and in our royall pallace there, the 25th day of March anno 1636.

Charles R.

English Letter 85 .

V

Charles II to Tsar alexis

Cologne, 30 July 1655.

Most excellent and renowned Prince. Amongst the severall perplexities we haue lately suffered in our distressed affaires, we haue been 
very sensibly afflicted, that we haue hetherto wanted convenient meanes to send, according to our intention, with our letters an expresse messenger, to make a returne vnto Your Imperiall Majesty of our thankfull acknow: ledgement and of the deepe resentement we haue of your singular favours, both in the kind reception of our right trusty and welbeloved counsellor John Lord Culpeper, Baron of Thoresway, and one of the peeres of our kingdome of England, 8 our embassadour extraordinary, and for the seasonable assistance and loane, which you so freely granted and he brought $\mathrm{v}$, of fourty thousand rixdollers, proceeding from the furres and corne, which you sent vs, ${ }^{9}$ as likewise for the high expression your Imperiall Majesty made of your love towards our person, the iust resentment of our distressed condition and your detestation of the execrable impiety of our rebellious subjects, together with your magnanimous offers and loving promises of the continuation of your affection and friendship to vs and further assistances in the time to come for the restablishment of our affaires; of all which our said ambassadour extraordinary hath fully and at large informed vs, wherein, as wee acknowledge that you haue infinitely obliged vs, we doe also assure Your Imperiall Majesty that we shall not only for ever preserue a gratefull memory of those favours, but shall not faile besides to make a full and just satisfaction for the said loane, so kindly and generously afforded vnto vs, so soone as it shall please God to restore vs to the lawfull possession of our Royail Crownes and inheritance, in the pursuite whereof we continually doe employ all possible endeavours; not doubting but, as there may be occasion, Your Imperiall Majesty will yet therein so affectionately further $\nabla s$, as thereby we may be the better enabled to render that recompense we owe vnto you, whensoeuer your affaires may any wise require it, and effectually to witnesse the true respect and high estimation we have of Your Imperiall Majesties friendship and fraternall affections towards vs. And thus wishing you, our deare brother, prosperity and glory in all your great designes, we leaue Your Imperiall Majesty to the blessed protection of the Almighty God. Given at our court at Collen, the xxxth day of July, in the yeare of our Lord MDCLV, and the seventh of our reigne.

Your most affectionate brother, Charles R.

\section{The Royal Veto under Charles II}

BETwEen the time a bill has passed both lords and commons and the time it is offered for the royal assent, an interval elapses during which the bill may be described as 'on the table'. The rules of parliament provide safeguards for the bill during this interval, which prevent either house from recalling it for any

- See 'The Relation of the Iord Culpepers Reception at the Emperiall Citie of Mosco, and his Lordshipps Quitting thereof, anno domini $1650^{\prime}$, printed in the Correspondence of Sir Edward Nicholas, ed by Sir G. F. Warner, i. (1886), 182-5.

- The loan was ' for three yeares time and no longer', and was ' not in redy money but delivered his Lordship in Corne and Furrs' : ibid., pp. $184 \mathrm{f}$. 